\title{
Viral Hepatitis Markers in Antepartum and Postpartum Women in Rio de Janeiro, Brazil
}

\author{
Lia Laura Lewis-Ximenez/*/+,Ana Maria Coimbra Gaspar, \\ Antonio Carlos Cavalieri D’Oro**: Luiz Antonio Chilelli Mercadante, \\ Cleber Ferreira Ginuino, Clara Fumiko Tachibana Yoshida
}

\begin{abstract}
Centro de Referência Nacional para Hepatites Virais, Departamento de Virologia, Instituto Oswaldo Cruz-Fiocruz, Av. Brasil 4365, 21045-900 Rio de Janeiro, RJ, Brasil *Department of Epidemiology, Harvard School of Public Health, Boston, MA, USA

**Hospital Maternidade Carmela Dutra, Rio de Janeiro, RJ, Brasil
\end{abstract}

A seroprevalence study was carried out among a group of women in Rio de Janeiro to determine the prevalence of different markers for viral hepatitis given the limited data among healthy populations. Blood samples collected and tested from 874 women before or after delivery in a public county maternity hospital demonstrated age to be directly related to markers for hepatitis A virus and hepatitis $B$ virus $(H B V)$ infection. The prevalence of $H B V$ and hepatitis $C$ virus infection were lower than that observed in the blood donor population and might be explained by the younger age group and gender.

Key words: seroprevalence - pregnant women - hepatitis - Rio de Janeiro - Brazil

The scarcity of population-based seroprevalence studies on viral hepatitis has led the Brazilian National Reference Center for Viral Hepatitis (BNRCVH) to perform studies on groups other than blood donors or individuals at risk of acquiring parenterally transmitted diseases. We here report the seroprevalence of viral hepatitis markers for hepatitis A (HAV), B (HBV), C (HCV), and E (HEV) virus infections among a female population in Rio de Janeiro, a city located in the Southeast region of Brazil.

Between April and May 1998, blood samples were withdrawn from 874 antepartum and postpartum women (mean age: 25 years) attending a public county maternity hospital, and from 446 newborn umbilical cords. The maternity hospital is located in a densely populated region, accommodates parturients from many different neighborhoods and averages up to 500 deliveries a month. Among the postpartum women, 310 had matched umbilical cord samples from their newborns. Serological testing included $\mathrm{HB}$ surface antigen (HBsAg), antibodies to hepatitis B core (anti-HBc), hepatitis B e antigen ( $\mathrm{HBeAg})$, antibody to $\mathrm{HBeAg}$ (anti-HBe), and anti-HCV (Organon Teknika, Boxtel, The Netherlands); anti-HAV (Bio-ManguinhosFiocruz, Brazil); and anti-HEV (Abbott, Chicago, IL). Anti$\mathrm{HCV}$ was initially tested by an enzyme-linked immunoassay and positive results were submitted to confirmatory testing (LIA-TEK, Organon Teknika). Testing for HBsAg was carried out within $24 \mathrm{~h}$ of blood sampling to quickly

This work was supported by Faperj, CNPq, and Colab/MS. ${ }^{+}$Corresponding author. Fax: +55-21-2270.6397. E-mail: 1llewis@gene.dbbm.fiocruz.br

Received 25 June 2001

Accepted 13 September 2001 identify any infected mother and initiate prophylactic measures for the newborns (HB immune globulin and vaccination).

The oldest age group had the highest prevalence for past viral infection (anti-HBc and anti-HAV) and the frequency of different viral markers for hepatitis is demonstrated in the Table. Among the 446 umbilical cord samples collected, anti-HBc and anti-HCV were detected in 25 $(5.7 \%)$ and in one sample $(0.2 \%)$, respectively. No umbilical cord samples were positive for HBsAg. Among the 310 postpartum women with matched umbilical cord samples, 26 were anti-HBc positive, of which $22(84.6 \%)$ paired newborn samples were similarly positive. There was only one paired parturient who was anti-HCV positive and whose newborn's umbilical cord sample was also positive.

The seroprevalence of anti-HAV showed a steady increase with age, reaching more than $90 \%$ in the $31-50$ age group (Table), suggesting an intermediate endemicity for $\mathrm{HAV}$, which is characterized by susceptible younger age groups and sporadic outbreaks (Tapia-Comyer et al. 1999). Hepatitis A outbreaks among young children in day-care centers and schools are frequently reported to the BNRCVH and, in 1999, our group evaluated three isolated outbreaks during a five-month period (unpublished). It was not surprising to find that the two positive cases for $\mathrm{HEV}$ in the present study were simultaneously positive for HAV since both share the same fecal-oral route of transmission. Previous studies on HEV have been primarily limited to the North and Northeastern regions of Brazil and were not population-based (Parana et al. 1997). In Brazil, this is the first seroprevalence study on HEV in pregnant women, and its low prevalence indicates that HEV does not seem to circulate freely among this population. 
TABLE

Serological markers for viral hepatitis according to age

\begin{tabular}{|c|c|c|c|c|c|c|c|c|c|c|}
\hline \multirow{3}{*}{ Age category } & \multirow{2}{*}{\multicolumn{2}{|c|}{ Anti-HAV }} & & & \multicolumn{4}{|c|}{$\mathrm{HBV}$} & & \\
\hline & & & \multicolumn{2}{|c|}{ Anti-HEV } & \multicolumn{2}{|c|}{ Anti-HBc } & \multicolumn{2}{|c|}{$\mathrm{HBsAg}$} & \multicolumn{2}{|c|}{ Anti-HCV } \\
\hline & $\mathrm{n}$ & $\%$ & $\mathrm{n}$ & $\%$ & $\mathrm{n}$ & $\%$ & $\mathrm{n}$ & $\%$ & $\mathrm{n}$ & $\%$ \\
\hline $12-20$ & $196 / 247$ & 79 & $1 / 85$ & 1.2 & $10 / 247$ & 4.1 & $0 / 247$ & 0 & $1 / 247$ & 0.4 \\
\hline $21-30$ & $256 / 303$ & 84 & $0 / 95$ & 0 & $24 / 303$ & 7.9 & $4 / 303$ & 1.3 & $2 / 302$ & 0.7 \\
\hline $31-50$ & $139 / 153$ & 91 & $0 / 59$ & 0 & $19 / 153$ & 12.4 & $0 / 153$ & 0 & $1 / 153$ & 0.7 \\
\hline Unknown & $144 / 171$ & 84 & $1 / 53$ & 1.9 & $10 / 171$ & 5.8 & 0/171 & 0 & $0 / 171$ & 0 \\
\hline Total & $735 / 874$ & 84 & $2 / 292$ & 0.7 & $63 / 874$ & 7.2 & $4 / 874$ & 0.5 & $4 / 874$ & 0.5 \\
\hline
\end{tabular}

HAV: hepatitis A virus; HEV; hepatitis E virus; HBc: hepatitis B core; HBsAg: hepatitis B surface antigen; HCV: hepatitis C virus

The results obtained on $\mathrm{HBsAg}$ and anti-HBc seroprevalence confirm the low endemicity for HBV infection (Silveira et al. 1999) in the Southeastern region of Brazil. The higher prevalence observed in those older than 20 years might be explained by an expected increase number of events over time that may lead to infection through sexual, intrafamiliar or parenteral exposure. Among the four women positive for $\mathrm{HBsAg}$ two were postpartum. One lacked prenatal care and the other had tested negative for HBsAg during early pregnancy. Since these samples were collected before the nationwide immunization program for HB vaccination in newborns in 1998 it might provide useful baseline data for the overall female population in this county and emphasizes the importance of immediate vaccination in newborns to prevent neonatal infection.

The low seroprevalence observed for anti-HCV $(0.5 \%)$ in this study might be related to differences in age and gender in comparison to other studies that have been mostly conducted in male blood donors older than 18 (1.3\%) (Martelli et al. 1999). A study among pregnant women in the Central region of Brazil had reported similarly lower levels of $\mathrm{HCV}$ infection when compared to a regional blood donor population (Martins et al. 1995).

Given the findings of the present study, HAV and HBV immunization programs among adolescents in Brazil should be considered, and larger population-based studies should be conducted to evaluate the extent of $\mathrm{HCV}$ infection in the Brazilian population.

\section{ACKNOWLEDGMENTS}

To Dr Sherrri Stuver for discussing and reviewing this paper.

\section{REFERENCES}

Martelli CMT, Turchi MD, Souto FJD, Sáez-Alquézar A, Andrade ALSS, Zicker F 1999. Anti-HBc testing for blood donors in areas with intermediate hepatitis B endemicity. Rev Panam Salud Publica 6: 69-73.

Martins RMB, Vanderborght BOM, Rouzere C, Cardoso DDP, Azevedo MSP, Yoshida CFT 1995. Anti-HCV prevalence and risk factors analysis in pregnant women in Central Brazil. Mem Inst Oswaldo Cruz, 90: 11.

Parana R, Cotrim HP, Cortey-Boennec ML, Trepo C, Lyra L 1997. Prevalence of hepatitis E virus IgG antibodies in patients from a referral unit of liver diseases in Salvador, Bahia, Brazil. Am J Trop Med Hyg 57: 60-61.

Silveira TR, da Fonseca JC, Rivera L, Fay OH, Tapia R, Santos JI, Urdeneta E, Clemens SA 1999. Hepatitis B seroprevalence in Latin America. Rev Panam Salud Publica 6: 378383.

Tapia-Conyer R, Santos JI, Cavalcanti AM, Urdaneta E, Rivera L, Manterola A, Potin M, Ruttimaan R, Tanaka Kido J 1999. Hepatitis A in Latin America: a changing epidemiologic pattern. Am J Trop Med Hyg 61: 825-829. 